\title{
Filling distribution gaps: new records of the Brazilian Porcupine, Coendou prehensilis (Linnaeus, 1758) (Mammalia, Rodentia), in 10 departments of Colombia
}

\author{
Héctor E. Ramírez-Chaves ${ }^{1,2}$, Juan Pablo López-Ordóñez ${ }^{3}$, Carlos A. Aya-Cuero ${ }^{4}$, Daniela \\ Velásquez-Guarín ${ }^{1,2}$, Alexandra Cardona-Giraldo ${ }^{5}$, Natalia Atuesta-Dimian ${ }^{6}$, Darwin M. Morales- \\ Martínez ${ }^{6}$, Miguel E. Rodríguez-Posada
}

1 Grupo de Investigación Genética, Biodiversidad y Manejo de Ecosistemas, Departamento de Ciencias Biológicas, Facultad de Ciencias Exactas y Naturales, Universidad de Caldas, Calle 65 No 26-10, Cod. Postal 170004, Manizales, Caldas, Colombia. 2 Centro de Museos, Museo de Historia Natural, Universidad de Caldas, Calle 65 \# 26-10, Manizales, Caldas, Colombia. 3 Conservación Internacional Colombia, Carrera 13 \# 71-41, Bogotá, Colombia. 4 Fundación Kurupira, Diagonal 16B No. 106-65, Bogotá D.C., 110921-243, Colombia. 5 Programa Maestría en Tecnologías de la Información Geográfica, Facultad de Ciencias e Ingeniería, Universidad de Manizales, Carrera 9a \# 19-03, Manizales, Caldas, Colombia. 6 Instituto Amazónico de Investigaciones Científicas SINCHI, Programa Ecosistemas y Recursos Naturales - Fauna, grupo de investigación Fauna Amazónica Colombiana, Calle 20 \# 5-44, Bogotá, Colombia. 7 Fundación Reserva Natural La Palmita, Centro de Investigación, Grupo de investigaciones territoriales para el uso y conservación de la biodiversidad, Bogotá, Colombia.

Corresponding author: Héctor E. Ramírez-Chaves, hector.ramirez@ucaldas.edu.co

\begin{abstract}
The Brazilian Porcupine, Coendou prehensilis (Linnaeus, 1758), is the most widespread species of Coendou Lacépède, 1799 in South America, but little is known on its natural history, ecology and distribution. In Colombia, it has been reported in the lowlands and inter-Andean valleys of 18 continental departments, but there are still gaps on its distribution, natural history and ecology. We present new distribution records and add information of the presence of $C$. prehensilis in 10 additional departments of Colombia located at the Amazonia, Orinoco, Peri-Caribbean Arid Belt, and North Andean Biogeographic provinces. We suggest that $C$. prehensilis is the most widespread species in the lowlands of Colombia, although it does not occur in the Biogeographic Chocó and in the inter-Andean medium and high valleys of the Cauca and Magdalena rivers.
\end{abstract}

\section{Keywords}

Amazonia, Andes, Caribbean, Erethizontidae, photographs, quills.

Academic editor: Guilherme Garbino | Received 8 June 2020 | Accepted 21 July 2020 | Published 28 July 2020

Citation: Ramírez-Chaves HE, López-Ordóñez JP, Aya-Cuero CA, Velásquez-Guarín D, Cardona-Giraldo A, Atuesta-Dimian N, Morales-Martínez DM, Rodríguez-Posada ME (2020) Filling distribution gaps: new records of the Brazilian Porcupine, Coendou prehensilis (Linnaeus, 1758) (Mammalia, Rodentia), in 10 departments of Colombia. Check List 16 (4): 927-932. https://doi.org/10.15560/16.4.927

\section{Introduction}

The genus Coendou Lacépède, 1799 (Rodentia, Erethizontidae) comprises 14 or 15 species of Neotropical porcupines (Voss 2015; Barthelmess 2016). Most of the richness of the genus is represented in Brazil, Colombia, and Ecuador (Voss 2015; Ramírez-Chaves et al. 2016; Menezes et al. 2020). In Colombia, six species 
of porcupines have been recorded (Ramírez-Chaves et al. 2016). Knowledge of the distribution and biology of Coendou in Colombia has increased in the last decade (Voss 2011, 2015; Racero-Casarrubia et al. 2016; Ramírez-Chaves et al. 2016, 2019; Leon-Alvarado and Ramírez-Chaves 2017; Gonzalez-Astudillo et al. 2018; Torres-Martínez et al. 2019). However, there are still several gaps in the distribution for most Coendou species in the country due to the few specimens in natural history collections, which limit our knowledge on the distribution patterns of the species of the genus (Alberico et al. 1999; Ramírez-Chaves et al. 2016).

The Brazilian Porcupine, Coendou prehensilis (Linnaeus, 1758), is potentially the most widely distributed porcupine in the lowlands of Colombia, with records in 17 continental departments and expected presence in the departments of Arauca, Cauca, Nariño, Guainía, Huila, Santander, and Vaupés (Torres-Martínez et al. 2019). The records come mainly from the Amazonia, Orinoco, Peri-Caribbean Arid Belt, Guyana, and North Andean Biogeographic provinces (Ramírez-Chaves et al. 2016; Racero-Casarrubia et al. 2016; Torres-Martínez et al. 2019). Despite its wide distribution, C. prehensilis has scarcely been studied, and there are several gaps in this species' distribution, ecology, and natural history.

To assist in filling these gaps, we provide an updated compilation of the distributional records of C. prehensilis and present an updated map of the species in Colombia based on new records and a review of the literature.

\section{Methods}

The new records of the Brazilian Porcupine are based on photographs of live specimens and also of road-killed and hunted animals, quills found in the field, and specimens housed in natural history collections. The collections visited and their acronyms are: Museo de Historia Natural, Universidad de Caldas (MHN-UCa), Manizales, Colombia; the Instituto de Ciencias Naturales, Universidad Nacional de Colombia (ICN), Bogotá; and The Field Museum of Natural History (FMNH), Chicago, United States.

We also reviewed voucher specimens from the departments of Caldas and Santander in the interAndean valley of the Middle Magdalena river basin of Colombia, where the species has been recorded (Villanueva 2006; Castaño Salazar 2012) and that were not included by Torres-Martínez et al. (2019) in the most recent publication on the distribution of $C$. prehensilis in Colombia. Similarly, we reviewed photographic records from specific localities in the Department of Boyacá, Municipality of Zetaquira $\left(05^{\circ} 15^{\prime} 55.23^{\prime \prime} \mathrm{N}\right.$, $073^{\circ} 10^{\prime} 08^{\prime \prime} \mathrm{W}$; 1,667 m a.s.1; CORPOBOYACÁ 2018); Department of Meta, Acacías "Bosque Los Guayupes" (0407'59.7"N, 07351'09"W; 1,730 m a.s.1); Vereda Portachuelo $\left(04^{\circ} 08^{\prime} 24.468^{\prime \prime} \mathrm{N}, 073^{\circ} 48^{\prime} 34.775^{\prime \prime} \mathrm{W} ; 1,313 \mathrm{~m}\right.$ a.s.l.; Rodríguez-Bolaños et al. 2014); and Puerto Gaitán, Tillavá river basin $\left(04^{\circ} 00^{\prime} 34.499^{\prime \prime} \mathrm{N}, 071^{\circ} 16^{\prime} 32.998\right.$;
153 m a.s.l.; Rodríguez-Bolaños et al. 2015), not included in previous distribution updates.

\section{Results}

We present new records of Coendou prehensilis in 10 departments of Colombia. The records are based on quills (three records), roadkills (two records), and photographs of hunted or live specimens (15 records) (Fig. 1). We also include three localities based on photographs of live specimens. In total, we add 20 new localities to the distribution of $C$. prehensilis in Colombia. The records come from an elevational range between 100 and $1,730 \mathrm{~m}$.

\section{Coendou prehensilis (Linnaeus, 1758)}

Figure 1

New records. COLOMBIA $\bullet 1$ juvenile female; Department of Arauca, Municipality of Arauquita, "Vereda" La Osa, Caño Limón Oil Field, firefighter school "Los Gavanes"; 0656'1.77"N, 071¹0'16.11"W; 149 m a.s.l.; 11 April 2008; Miguel E. Rodríguez-Posada leg; it was found sleeping in a tree next to the house; ICN 21902 (Fig. 1A, B). - Quills; Department of Arauca, Municipality of Arauca, "Vereda" Las Plumas, Los Cunaguaros; $06^{\circ} 36^{\prime} 15^{\prime \prime} \mathrm{N}, 070^{\circ} 29^{\prime} 52^{\prime \prime} \mathrm{W} ; 112 \mathrm{~m}$ a.s.l; 30 November 2018; Daniela Velásquez-Guarín leg; found in gallery forest near a cubarro palm (Bactris major Jacq.); MHN-UCa 2079 (Fig. 1C). • Quills; Department of Arauca, Municipality of Arauca, "Vereda" Las Plumas, "Finca" Las Piñas; 06³5'16.7"N, 070³0'9.80"W; 110 m a.s.l.; 30 November 2018; Daniela VelásquezGuarín leg; found in the base of the moriche palm trunk (Mauritia flexuosa L.f.); MHN-UCa 2080 • 1 adult; Department of Caquetá, Municipality of San Vicente del Caguán, "Vereda" Los Andes, Pato River middle basin; 02³4' $9.037^{\prime \prime} \mathrm{N}, 074^{\circ} 43^{\prime} 19.356^{\prime \prime} \mathrm{W} ; 720 \mathrm{~m}$ a.s.1; 16 May 2018; photographed by Carlos Aya-Cuero in a secondary forest (Fig. 1D). • 1 adult; Department of Casanare, Municipality of Aguazul, "Vereda" La Graciela, “finca” Las Delicias; 0441'13.204"N, 072²4'48.481"W; 192 m a.s.l.; 11 October 2013; photographed by Darwin Morales-Martínez at 20:00 h inside a riparious forest (Fig. 1E). 1 adult; Department of Casanare, Municipality of Paz de Ariporo, "Vereda" Bebedero, "finca" Las Malvinas; $05^{\circ} 49^{\prime} 53.1^{\prime \prime} \mathrm{N}, 071^{\circ} 51^{\prime} 48.1^{\prime \prime} \mathrm{W} ; 236 \mathrm{~m}$ a.s.1.; 5 January 2011; photographed by Miguel E. Rodríguez Posada at 20:00 $\mathrm{h}$ in a mango tree (Mangifera indica $\mathrm{L}$.) (Fig. 1F). 1 adult; Department of Casanare, Municipality of Trinidad, "Vereda" La Cañada, La Palmita Natural Reserve; 05²5'12.33"N, 071³6'2.57"W; $160 \mathrm{~m}$ a.s.l.; repeatedly observed next to the house on mango trees. - 1 adult; Department of Cauca, Municipality of Piamonte, "Vereda" El Convenio; 0101'26.9"N, 076²19' 59.2"W; 300 m a.s.1.; 24 April 2020; photographed by José Paz at 21:40 h (Fig. 1G, H); the porcupine was not afraid of people in the camp and came closer to lick salt 

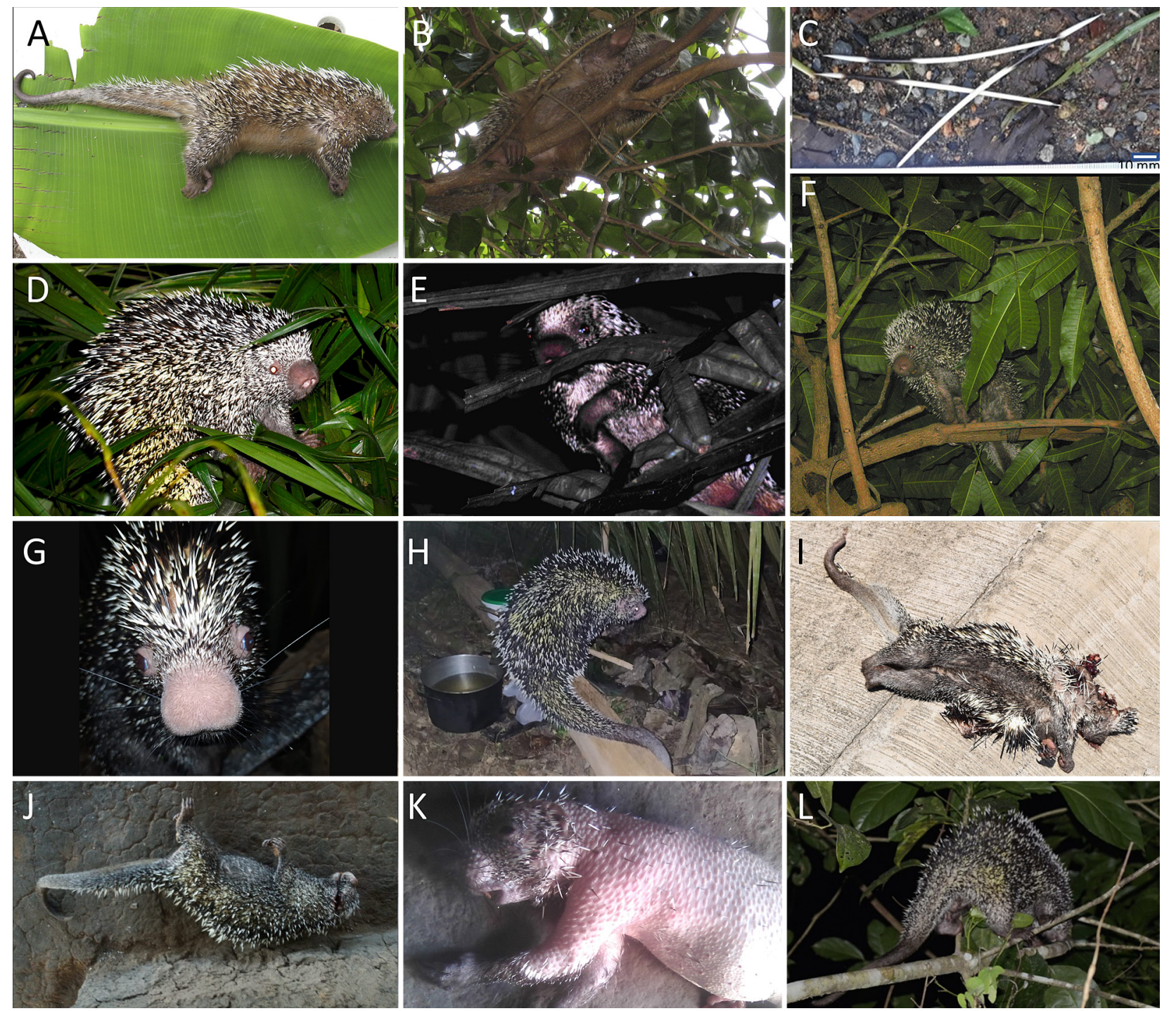

Figure 1. New records of the Brazilian Porcupine, Coendou prehensilis, from Colombia. A-B. Individual from the Department of Arauca. C. Tricolored quills from the Department of Arauca. D. Adult specimen from Department of Caquetá. E, F. Adult individuals from the Department of Casanare. G. Inflated external nostrils and tricolored quills of a specimen from the Department of Cauca. $\mathbf{H}$. Individual from the Department of Cauca searching for salt in a human camp. I. Road-killed individual from the Department of Cundinamarca. J, K. Details of hunted porcupines from the Department of Guainía for human consumption. L. Details of the length of the tail of an adult individual from the Department of La Guajira (northernmost locality record).

that was in a plastic dish (Fig. 1H). • 2 adults; Department of Cundinamarca, Municipality of Paratebueno, in the Villavicencio (Meta)-Yopal (Casanare) road; 04 $26^{\prime} 18.589^{\prime \prime} \mathrm{N}, 073^{\circ} 10^{\prime} 20.611^{\prime \prime} \mathrm{W} ; 250 \mathrm{~m}$ a.s.1.; 30 April 2020; photographed by Adrián Vasquez (Fig. 1I); two individuals were found roadkilled in this locality. 2 adults; Cundinamarca: Municipality of Medina, Humea River; $04^{\circ} 24^{\prime} 14.795^{\prime \prime} \mathrm{N}, 073^{\circ} 17^{\prime} 38.519^{\prime \prime} \mathrm{W} ; 320 \mathrm{~m}$ a.s.1; 20 January 2014, photographed by William Vega inside a tree hole. 1 adult; Department of Guainía, Municipality of Inírida, Indigenous reservation Almidón-La Ceiba, community of La Ceiba; 0337'37.09" N, 067 $54^{\circ}$ 25.79"W; 102 m a.s.1; 24 June 2019; photographed by Wilber Suárez in community monitoring project for subsistence hunting (Fig. 1J). • 1 adult; Department of Guainía, Municipality of Inírida, Indigenous reservation Caranacoa-Yurí-Laguna Morocoto, community

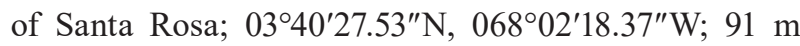

a.s.1; 28 June 2019; photographed by Ricardo Medina in community monitoring project for subsistence hunting (Fig. 1K). • Quills; Department of Guainía, Municipality of Inírida, Indigenous reservation Caranacoa-YuríLaguna Morocoto, community of Caranacoa, Caño Chubano; $03^{\circ} 46^{\prime} 50.61^{\prime \prime} \mathrm{N}, 068^{\circ} 00^{\prime} 39.50^{\prime \prime} \mathrm{W}$; 103 m a.s.1; 14 June 2019; ICN uncatalogued; the quills were taken from a male porcupine hunted for consumption. - 1 adult; Department of Guaviare, Municipality of San José del Guaviare, "Vereda" Raudal del Guayabero; 02³4' 47.0"N; 072 51'57.7"W; 198 m a.s.1; 15 June 2017; an individual observed during nightly sampling moving in the canopy of a tree, ca $3 \mathrm{~m} \cdot 1$ adult; Department of La Guajira, Municipality of Palomino, "Vereda" San Salvador; $11^{\circ} 12^{\prime} 7.073^{\prime \prime} \mathrm{N}, 073^{\circ} 32^{\prime} 6.201^{\prime \prime} \mathrm{W}$; $65 \mathrm{~m}$ a.s.1.; 13 January 2019; photographed by Carlos Aya-Cuero (Fig. 1L). 2 adults; Department of La Guajira, Riohacha, "Vereda" Los Gorros; $11^{\circ} 3^{\prime} 22^{\prime \prime} \mathrm{N}, 072^{\circ} 55^{\prime} 44^{\prime \prime} \mathrm{W} ; 414 \mathrm{~m}$ a.s.1; 15 
December 2018; recorded (photographs and video) by Carlos Aya-Cuero inside the cavity of a tree that felt due to strong winds.

Identification. We identified the specimens as C. prehensilis based on external traits (Fig. 1), such as large body size and tail (it is the largest species found in Colombia), inflated external nostrils, and tricolored quills (bright yellow at the base, black in the middle, and whitish-yellow at the distal portion), and comparison with specimens deposited in the reviewed collections. Other large species of Coendou in South America are C. bicolor (Tschudi, 1844), which differs from C. prehensilis by lacking the distal bands on its quills and has no tricolored quills on the rump (Voss 2015; Menezes et al. 2020), and C. baturitensis Feijó \& Langguth, 2013, which is externally similar to C. prehensilis, but endemic to Brazil (Menezes et al. 2020).

\section{Discussion}

Our records fill distribution gaps and provide new information on Coendou prehensilis in 10 departments of Colombia. Among the new records, the presence of the species was expected in some localities (e.g., departments of Guainía and La Guajira), or was not supported by evidence until the present study (e.g., departments of Arauca and Cundinamarca) (Fig. 2). Our results suggest that $C$. prehensilis is the most widespread porcupine in Colombia, with at least 51 locality records (Fig. 2; Ramírez-Chaves et al. 2016; Torres-Martínez et al. 2019). We also provide the northernmost known record of $C$. prehensilis, in the Caribbean region of Colombia (Marinho-Filho and Emmons 2016). We provide the first confirmed localities for the departments of Cauca, Guainía, and La Guajira, and clarify the presence or present new records in the departments of Arauca, Boyacá, Caquetá, Casanare, Cundinamarca, Guaviare, and Meta (Fig. 2).

From the Department of Cauca, only Coendou rufescens (Gray, 1865) had been previously reported (Ramírez-Chaves and Pérez 2010). From the Department of Guainía, there were only records of Coendou pruinosus Thomas, 1905 (Ramírez-Chaves et al. 2016). From La Guajira, the presence of $C$. prehensilis was expected (Torres-Martínez et al. 2019) based on the proximity of the records in neighboring departments that share the Sierra Nevada de Santa Marta, where is the type locality of Coendou sanctaemartae Allen, 1904 (a junior synonym of C. prehensilis sensu lato; Voss et al. 2013; Ramírez-Chaves 2014; Torres-Martínez et al. 2019).

For departments with records not fully described such as Arauca, at least two species of Coendou have been reported (C. pruinosus, C. prehensilis, and Coendou sp.; Mosquera-Guerra et al. 2019). Our records for Arauca are based on vouchers (e.g., ICN 21902) that can be safely identified as belonging to $C$. prehensilis due to their size and tricolored banding pattern (Fig. 1A). The quills of $C$. pruinosus are smaller and bicolored (Voss 2011).

Similarly, for the Department of Boyacá, previous records of Coendou come from Pajarito; "Vereda" Corinto $\left(05^{\circ} 17^{\prime} 35^{\prime \prime} \mathrm{N}, 072^{\circ} 42^{\prime} 11^{\prime \prime} \mathrm{W} ; 793\right.$ m a.s.l.; ICN 3033; Torres-Martínez et al. 2019) for C. prehensilis, and from Páez, "Vereda" El Tunjo (ICN 123) for Coendou cf. bicolor (Ramírez-Chaves et al. 2016). A comparison of ICN 123 (from the Department of Boyacá) with specimens of C. bicolor from Peru (FMNH 41204, 65800), and $C$. prehensilis from Colombia, Ecuador, Peru, Suriname, and Trinidad (FMNH 20031, 41205, 43290, 61862, 61863,95783 ) showed that ICN 123 is more similar to $C$. prehensilis than to $C$. bicolor. Furthermore, the lack of confirmed records of $C$. bicolor from Colombia (closest records are from the Amazon region of Peru and Brazil; Voss 2015; Menezes et al. 2020) and the fact that the only species found to date in Boyacá is C. prehensilis, supports the hypothesis that the ICN 123 skull represents C. prehensilis.

Coendou prehensilis was the only porcupine recorded in the Department of Casanare, where it is known from two localities (Fig. 2) based on photographs (Torres-Martínez et al. 2019). Previous records in the Department of Cundinamarca were considered erroneous because the specimen, from the western slopes of the department in the Cordillera Oriental (Eastern Cordillera of Colombia), was a mixed (mismatched) specimen of two species (C. rufescens and C. prehensilis; Torres-Martínez et al. 2019). Our records confirm the presence of C. prehensilis only in the eastern slopes of the Cordillera Oriental. The presence of $C$. prehensilis in the Middle Magdalena river basin (eastern slope of Central Cordillera and western slope of Eastern Cordillera) lacks empirical support. Our review of specimens at the MHN-UCa (MHNUCa 787, 1272, 1616, 2422-2423) and ICN (ICN 2015), as well as previous records from the departments of Caldas (Castaño Salazar 2012) and Santander (Villanueva 2006), determined them to be Coendou quichua Thomas, 1899 (sensu lato), based on the flat (not inflated) frontal sinuses and smaller size.

The new records shown here come from distinct environments such as forested areas of the Amazon region, Sub-Andean forests, and riparian forest immersed in savannahs of the Orinoco river basin. This suggests that the species is flexible and generalist in terms of habitat use, and perhaps in its diet, considering that $C$. prehensilis is the most widespread species of the genus among natural regions and biogeographic provinces of Colombia (Torres-Martínez et al. 2019). Finally, occasional records are key for planning of conservation strategies on a broader landscape scale in Colombia, considering that the species has several threats, especially hunting (Racero-Casarrubia et al. 2016; Salcedo-Rivera et al. 2018) and roadkills. As suggested by other authors (e.g., de Freitas et al. 2013; Gregory et al. 2015), the use of less conventional sources of information, such as roadkills or camera traps, should be used to obtain important data on this poorly known porcupine species. 


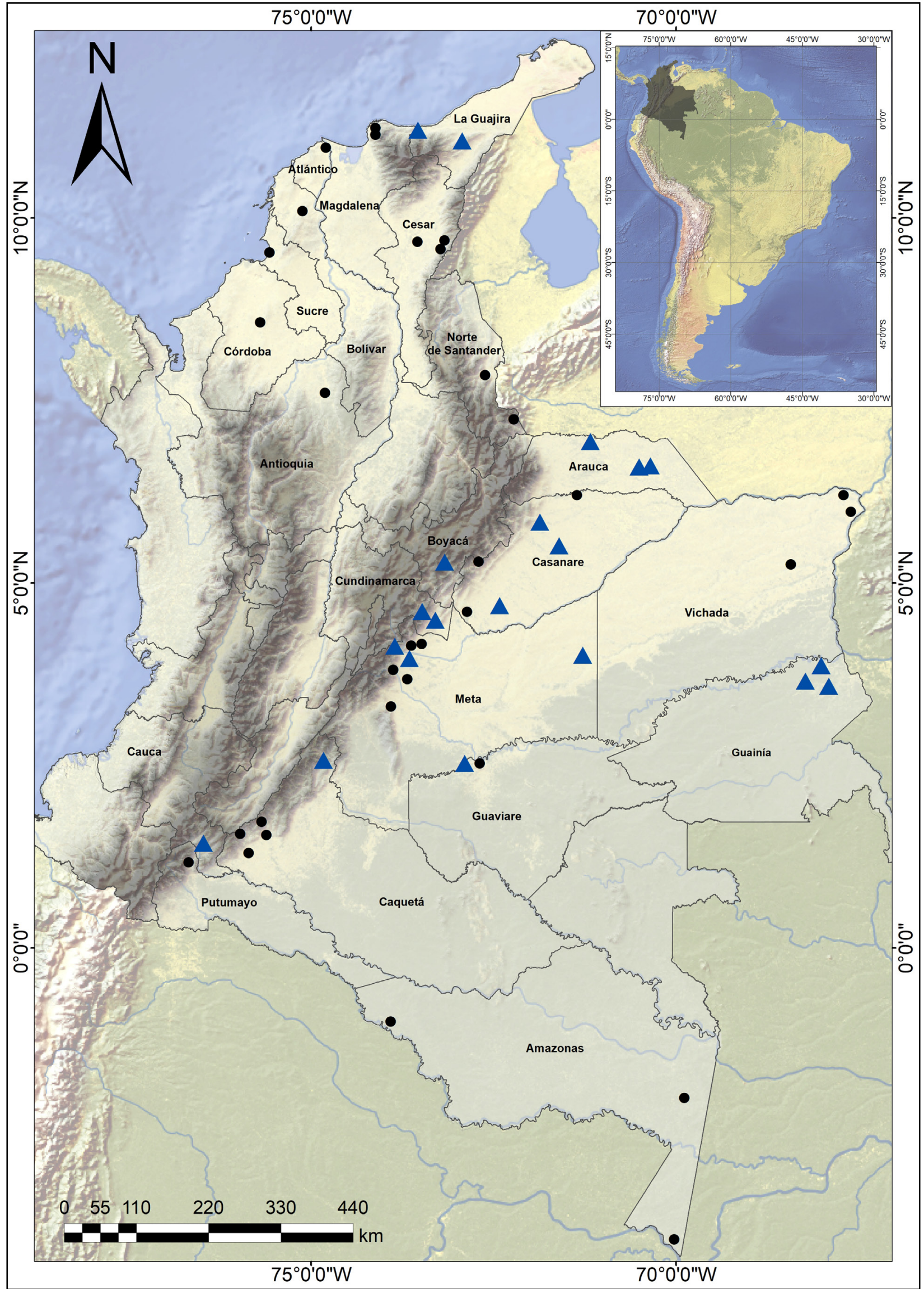

Figure 2. Updated distribution of Coendou prehensilis in Colombia. New records (blue triangles) include first records for three departments of Colombia (Cauca, Guainía, and La Guajira), and new confirmed records from the departments of Arauca, Boyacá, Casanare, Caquetá, Cundinamarca, Guaviare, and Meta. Black dots show previous records in the literature (Torres-Martínez et al. 2019). 


\section{Acknowledgements}

We thank Jorge Peña, Adrián Vásquez-Ávila, and Willian Vega for sharing their field observations and photographs. The Vicerrectoría de Investigaciones y Posgrados of Universidad de Caldas and the Ministry of Science, Technology, and Innovation of Colombia (MinCiencias) funded the project (code 112777758193; execution contract number 858-2017). Thanks are also given to the Vicerrectoría de Investigaciones, Universidad de Caldas (project 0743919). HERC thanks Bruce D. Patterson and the Science and Scholarship Committee of the Field Museum of Natural History, Chicago, and Rufford Small Grants (grants 23710-1 and 29491-2) for support.

\section{Authors' Contributions}

HERC and ACG collected data from museums, analyze the data, prepared maps and figures and wrote the paper. JPLO, CAC, DVG, DMM, NAD, and MRP collected data in the field and wrote the paper.

\section{References}

Alberico M, Rojas-Díaz V, Moreno JG (1999) Aporte sobre la taxonomía y distribución de los puercoespines (Rodentia: Erethizontidae) en Colombia. Revista de la Academia Colombiana de Ciencias Exactas, Físicas y Naturales 23: 595-612.

Barthelmess EL (2016) Family Erethizontidae. In: Wilson DE, Lacher Jt TE, Mittermeier RA, (Eds) Handbook of mammals of the world. Vol. 6. Lagomorphs and rodents: part 1. Lynx Edicions, Barcelona, 372-397.

Castaño Salazar JH (2012) Mamíferos de Caldas: Un análisis de vacíos de información. Boletín Científico, Centro de Museos, Museo de Historia Natural 16 (2): 101-119.

CORPOBOYACÁ (2018) Fue rescatado y liberado un Puercoespín Arborícola en Zetaquira. https://www.corpoboyaca.gov.co/ noticias/fue-rescatado-y-liberado-un-puercoespin-arboricola-enzetaquira/. Accessed on: 2020-5-1.

de Freitas MA, de França DPF, Veríssimo D (2013) First record of the Bicoloured-spined Porcupine Coendou bicolor (Tschudi, 1844) for Brazil. Check List 9 (1): 94-96. https://doi.org/10.15560/9.1.94

Gonzalez-Astudillo V, Leon-Alvarado OD, Ossa-Lopez PA, RiveraPáez FA, Ramírez-Chaves HE (2018) Sarcoptic mange in wild Quichua Porcupines (Coendou quichua Thomas, 1899) in Colombia. International Journal for Parasitology: Parasites and Wildlife 7 (1): 95-98. https://doi.org/10.1016/j.ijppaw.2018.02.002

Gregory T, Lunde D, Zamora-Meza HT, Carrasco-Rueda F (2015) Records of Coendou ichillus (Rodentia, Erethizontidae) from the Lower Urubamba Region of Peru. ZooKeys 509: 109-121. https:// doi.org/10.3897/zookeys.509.9821

Leon-Alvarado OD, Ramírez-Chaves HE (2017) Morphological description of the glans penis and baculum of Coendou quichua (Rodentia: Erethizontidae). Therya 8 (3): 263-268. https://doi.org/ 10.12933/therya-17-495

Marinho-Filho J, Emmons L (2016) Coendou prehensilis. The IUCN Red List of Threatened Species 2016: e.T101228458A22214580. https://doi.org/10.2305/iucn.Uk.2016-2.Rlts.T101228458a22214 580.en. Accessed on: 2020-5-1.

Menezes FH, Garbino GST, Semedo TBF, Lima M, Feijó A, Cordeiro-Estrela P, Da Costa IR (2020) Major range extensions for three species of porcupines (Rodentia: Erethizontidae: Coendou) from the Brazilian Amazon. Biota Neotropica 20 (2): e20201030. https://doi.org/10.1590/1676-0611-BN-2020-1030

Mosquera-Guerra F, Trujillo F, Aya Cuero C, Bolívar L, Valencia K, Vargas Arboleda AF, Mantilla Meluk H (2019) Mamíferos. In: Trujillo F, Anzola F (Eds) Biodiversidad en el departamento de Arauca. Gobernación de Arauca, Fundación Omacha y Fundación Ecollano, Bogotá, 265-273.

Racero-Casarrubia J, Chacón-Pacheco J, Humanez-López E, Ramírez-Chaves HE (2016) Registros recientes de los puercoespines, género Coendou (Mammalia: Erethizontidae) para el departamento de Córdoba, Colombia. Biota Colombiana 17 (1): 137-142. https://doi.org/10.21068/C2016v17r01a11

Ramírez-Chaves HE (2014) Mammals of Colombia deposited at the Zoologische Staatssammlung Muenchen, Germany. Biota Colombiana 15 (1): 104-114.

Ramírez-Chaves HE, Pérez W (2010) Mamíferos (Mammalia: Theria) del departamento del Cauca, Colombia. Biota Colombiana 11 (1-2): 141-171.

Ramírez-Chaves HE, Suárez-Castro AF, Morales-Martínez DM, Vallejo-Pareja MC (2016) Richness and distribution of porcupines (Erethizontidae: Coendou) from Colombia. Mammalia 80 (2): 181-191. https://doi.org/10.1515/mammalia-2014-0158

Ramírez-Chaves HE, Torres-Martínez MM, Noguera-Urbano EA, Passos FC, Colmenares-Pinzón JE (2019) State of knowledge and potential distribution of the Colombian endemic Brown Hairy Dwarf Porcupine Coendou vestitus (Mammalia: Rodentia). Mammalian Biology 90: 1-11. https://doi.org/10.1016/j.mambio.2019.09.012

Rodríguez-Bolaños A, Carvajal-Rojas L, Ariza-Cortés W (2014) Fauna de los bosques los Guayupes - cuenca del río GuayuribaAcacías, Meta. Cormacarena, Universidad Distrital Francisco José de Caldas, Bogotá DC, 311 pp.

Rodríguez-Bolaños A, Carvajal-Rojas L, Ariza-Cortés W (2015) Fauna de los Bosques de las Cuencas de los ríos Planas y Tillavá, Puerto Gaitán, Meta, Colombia. Cormacarena, Universidad Distrital Francisco José de Caldas, Bogotá D.C., 280 pp.

Salcedo-Rivera GA, Fuentes-Mario JA, De La Ossa-V J (2018) Ethnozoological assessment of native rodents in rural areas of the Sucre Department, Colombia. Indian Journal of Science and Technology 11 (46): 1-8. https://doi.org/10.17485/ijst/2018/v11i46/137333

Torres-Martinez MM, Ramírez-Chaves HE, Noguera-Urbano EA, Colmenares-Pinzón JE, Passos FC, García J (2019) On the distribution of the Brazilian porcupine Coendou prehensilis (Erethizontidae) in Colombia. Mammalia 83 (3): 290-297. https://doi. org/10.1515/mammalia-2018-0043

Villanueva D (2006) Estudio de los mamíferos de la Serranía de los Yariguíes y su conservación. In: Huertas BC, Donegan TM (Eds) Proyecto YARÉ: Investigación y Evaluación de las Especies Amenazadas de la Serranía de los Yariguíes, Santander, Colombia. BP Conservation Programme. Informe Final. Colombian EBA Project Report Series 7: 55-66, 148-151.

Voss RS (2011) Revisionary notes on Neotropical porcupines (Rodentia, Erethizontidae). 3. An annotated checklist of the species of Coendou Lacépède, 1799. American Museum Novitates 3720: 1-36. https://doi.org/10.1206/3720.2

Voss RS (2015) Superfamily Erethizontoidea Bonaparte, 1845. In: Patton JL, Pardiñas UFJ, D'Elía G (Eds) Mammals of South America, volume 2, rodents. The University of Chicago Press, Chicago, 786-805.

Voss RS, Hubbard C, Jansa SA (2013) Phylogenetic relationships of New World porcupines (Rodentia, Erethizontidae): implications for taxonomy, morphological evolution, and biogeography. American Museum Novitates 3769: 1-36. https://doi.org/10.1206/3769.2 